\title{
The Gamma Interferon Knockout Mouse Model for Sarcocystis neurona: Comparison of Infectivity of Sporocysts and Merozoites and Routes of Inoculation
}

\author{
Author(s): J. P. Dubey, D. S. Lindsay, O. C H. Kwok, and S. K. Shen \\ Source: Journal of Parasitology, 87(5):1171-1173. 2001. \\ Published By: American Society of Parasitologists \\ DOI: http://dx.doi.org/10.1645/0022-3395(2001)087[1171:TGIKMM]2.0.CO;2 \\ URL: http://www.bioone.org/doi/full/10.1645/0022-3395\%282001\%29087\%5B1171\%3ATGIKMM \\ $\% 5 \mathrm{D} 2.0 . \mathrm{CO} \% 3 \mathrm{~B} 2$
}

BioOne (www.bioone.org) is a nonprofit, online aggregation of core research in the biological, ecological, and environmental sciences. BioOne provides a sustainable online platform for over 170 journals and books published by nonprofit societies, associations, museums, institutions, and presses.

Your use of this PDF, the BioOne Web site, and all posted and associated content indicates your acceptance of BioOne's Terms of Use, available at www.bioone.org/page/terms_of_use.

Usage of BioOne content is strictly limited to personal, educational, and non-commercial use. Commercial inquiries or rights and permissions requests should be directed to the individual publisher as copyright holder. 
American Society of Parasitology. J. P. Dubey, D. S. Lindsay, O. C H. Kwok, and S. K. Shen (2001). "The Gamma Interferon Knockout Mouse Model for Sarcocystis neurona: Comparison of Infectivity of Sporocysts and Merozoites and Routes of Inoculation," Journal of Parasitology, Vol. 87, No. 5, pp. 1171-1173. doi: http://

dx.doi.org/10.1645/0022-3395(2001)087[1171:TGIKMM]2.0.CO;2

\section{The Gamma Interferon Knockout Mouse Model for Sarcocystis neurona: Comparison of Infectivity of Sporocysts and Merozoites and Routes of Inoculation}

J. P. Dubey, D. S. Lindsay ${ }^{\star}$, O. C. H. Kwok, and S. K. Shen, United States Department of Agriculture, Agricultural Research Service, Animal and Natural Resources Institute, Parasite Biology, Epidemiology and Systematics Laboratory, Building 1001, Beltsville, Maryland $20705-2350$. ${ }^{*}$ Center for Molecular and Infectious Diseases, Department of Biomedical Sciences and Pathiobiology, Virginia-Maryland Regional College of Veterinary Medicine, Virginia-Tech, 1410 Prices Fork Road, Blacksburg, Virginia 24061-0342. email: jdubey@anri.barc.usda.gov

ABSTRACT: The dose-related infectivity of Sarcocystis neurona sporocysts and merozoites of 2 recent isolates of $S$. neurona was compared in gamma interferon knockout (KO) mice. Tenfold dilutions of sporocysts or merozoites were bioassayed in mice, cell culture, or both. All 8 mice, fed 1,000 sporocysts, developed neurological signs with demonstrable $S$. neurona in their tissues. Of 24 mice fed low numbers of sporocysts $(100,10,1), 18$ became ill by 4 wk postinoculation, and $S$. neurona was demonstrated in their brains; antibodies ( $S$. neurona agglutination test) to $S$. neurona and $S$. neurona parasites were not found in tissues of the 6 mice that were fed sporocysts and survived for $>39$ days. One thousand culture-derived merozoites of these 2 isolates were pathogenic to all 8 mice inoculated subcutaneously (s.c.). Of the 24 mice inoculated s.c. with merozoites numbering 100 , 10, or 1 , only 3 mice had demonstrable $S$. neurona infection; antibodies to $S$. neurona were not found in the 21 mice that had no demonstrable organisms. As few as 10 merozoites were infective for cell cultures. These results demonstrate that at least 1,000 merozoites are needed to cause disease in KO mice. Sarcocystis neurona sporocysts were infective to mice by the s.c. route.

Sarcocystis neurona is the most important cause of equine protozoal myeloencephalitis (EPM) in the horse, and EPM is the most commonly diagnosed neurologic disease of horses in the Americas (Dubey et al., 1991; MacKay et al., 1992; Dubey, Lindsay et al., 2001). The life cycle of $S$. neurona is not completely known. Opossums (Didelphis virginiana) are definitive hosts, and they excrete S. neurona sporocysts in feces (Fenger et al., 1997; Dubey and Lindsay, 1998). Horses and several other animal species (cats, ponies, zebra, raccoons, mink, skunk, Pacific harbor seals, sea otters) are considered aberrant intermediate hosts (reviewed by Dubey, Lindsay et al., 2001). In all of these aberrant hosts, including horses, only schizont stages have been identified and are confined to the central nervous system (CNS). Cats can act as experimental intermediate hosts and harbor the sarcocyst stage; the natural intermediate host is unknown (Dubey et al., 2000). Horses fed sporocysts de- veloped clinical signs and $S$. neurona-specific antibodies, but the parasite was not demonstrated in tissues (Fenger et al., 1997).

Certain strains of immunodeficient mice are susceptible to $S$. neurona infection (Marsh et al., 1996; Dubey and Lindsay, 1998). Gamma interferon gene knockout (KO) mice develop encephalitis after being fed sporocysts from opossums (Dubey and Lindsay, 1998). At present, little is known of the effect of dose on the development of clinical sarcocystosis in $\mathrm{KO}$ mice. In initial experiments, nude or $\mathrm{KO}$ mice inoculated parenterally with 10,000 or more cell culture-derived merozoites developed neural sarcocystosis (Marsh et al., 1997; Dubey and Lindsay, 1998). The period to development of clinical disease in KO mice after inoculation with merozoites is also not defined. Nothing is known of the sensitivity of the bioassays in cell culture or $\mathrm{KO}$ mice for isolating $S$. neurona from affected horses. For example, attempts to recover $S$. neurona from the CNS of horses fed $S$. neurona sporocysts have been unsuccessful using bioassay in cell culture (Fenger et al., 1997). Therefore, dose titrations of $S$. neurona sporocysts and merozoites in $\mathrm{KO}$ mice were performed.

The KO mice (BALB/c Inf ${ }^{\mathrm{mTs}}$ ) were bred in-house from stock mice (Jackson Laboratories, Bar Harbor, Maine). They were 26 to 51 days old when used in experiments; both males and females were used.

Sarcocystis neurona sporocysts were collected from the small intestine of 3 naturally infected opossums as described (Dubey, 2000; Dubey, Black et al., 2001). Sporocysts were suspended in antibiotic saline (Dubey et al., 1989) and stored at $4 \mathrm{C}$ until used. Three isolates (SN15OP; SN28-OP, SN29-OP) of S. neurona (Dubey, 2000; Dubey, Black et al., 2001) were used. Seven, 10 -fold dilutions $\left(10^{0}\right.$ to $\left.10^{-6}\right)$ of sporocysts were made in antibiotic saline and stored at $4 \mathrm{C}$. Aliquots $(0.5$ $\mathrm{ml}$ ) from each dilution were fed to $\mathrm{KO}$ mice by a stomach tube. The number of infective $S$. neurona sporocysts in the inoculum was estimated by bioassay in mice because 3 or more species of Sarcocystis may be present in opossums, and their sporocysts cannot be distinguished visually (Dubey and Lindsay, 1999; Tanhauser et al., 1999). Sera from mice were examined for antibodies to $S$. neurona in a $S$. 
TABLE I. Infectivity of graded doses of Sarcocystis neurona sporocysts of 2 isolates for gamma interferon knockout mice.

\begin{tabular}{|c|c|c|c|c|c|c|}
\hline \multirow[b]{2}{*}{ Dose* } & \multicolumn{3}{|c|}{ SN28-OP sporocysts } & \multicolumn{3}{|c|}{ SN29-OP sporocysts } \\
\hline & $\begin{array}{l}\text { Exam- } \\
\text { ined } \dagger\end{array}$ & Tissue & SAT & $\begin{array}{c}\text { Exam- } \\
\text { ined }\end{array}$ & Tissue & SAT \\
\hline \multirow{4}{*}{$\begin{array}{l}10^{-4} \\
(100)\end{array}$} & DK27 & $\mathrm{B}, \mathrm{E}, \mathrm{H}, \mathrm{Lu}$ & ND & DK22 & B & 50 \\
\hline & DK28 & $\mathrm{B}, \mathrm{Lu}$ & ND & DK26 & B & $>500$ \\
\hline & DK28 & $\mathrm{B}, \mathrm{Lu}$ & ND & DK30 & $\mathrm{B}, \mathrm{E}, \mathrm{Lu}$ & $>500$ \\
\hline & DK28 & $\mathrm{B}$ & ND & DK30 & $\mathrm{B}, \mathrm{T}$ & $>500$ \\
\hline \multirow{4}{*}{$\begin{array}{l}10^{-5} \\
(10)\end{array}$} & D28 & $\mathrm{B}, \mathrm{E}$ & ND & DK27 & B & $>500$ \\
\hline & DK28 & B & ND & DK27 & $\mathrm{B}, \mathrm{St}$ & $>500$ \\
\hline & K56 & None & $<25$ & DK28 & $\mathrm{B}$ & $>500$ \\
\hline & K56 & None & $<25$ & DK28 & $\mathrm{B}, \mathrm{H}, \mathrm{Lu}$ & $>500$ \\
\hline \multirow{4}{*}{$\begin{array}{l}10^{-6} \\
(1)\end{array}$} & DK28 & $\mathrm{B}$ & ND & DK28 & $\mathrm{B}, \mathrm{St}$ & $>500$ \\
\hline & DK38 & B & $>25$ & DK29 & $\mathrm{B}, \mathrm{Lu}$ & $>25$ \\
\hline & K56 & None & $<25$ & K56 & None & $<25$ \\
\hline & K56 & None & $<25$ & K56 & None & $<25$ \\
\hline \multirow{4}{*}{$\begin{array}{l}10^{-7} \\
(0)\end{array}$} & D4 & ND & ND & K65 & None & $<25$ \\
\hline & K65 & None & $<25$ & K65 & None & $<25$ \\
\hline & K65 & None & $<25$ & K65 & None & $<25$ \\
\hline & K65 & None & $<25$ & K65 & None & $<25$ \\
\hline
\end{tabular}

* Dilution of sporocysts fed with approximate number of infective sporocysts in parentheses.

$\dagger$ Clinical presentation and day postinoculation mouse was examined at necropsy. $\mathrm{D}$, died; K, killed; DK, killed when clinically ill.

\$ B, brain; E, eye; H, heart; Lu, lung; St, stomach; T, tongue.

$\S$ SAT, Sarcocystis neurona agglutination test. Values expressed as reciprocal titers.

neurona agglutination test (SAT) as described by Lindsay and Dubey (2001).

For histologic studies, all mice were examined at necropsy. Portions of brain, eyes, heart, lungs, liver, spleen, mesenteric lymph nodes, small intestine, kidneys, adrenals, uterus, testes, abdominal muscle, urinary bladder, skeletal muscle from legs, and tongue of mice fed sporocysts and brains of those injected subcutaneously (s.c.) with merozoites or sporocysts were fixed in buffered neutral $10 \%$ formalin. All sections of intestine and other tissues of each mouse were embedded in paraffin blocks and sections were cut at $5 \mu \mathrm{m}$ and examined microscopically after staining with hematoxylin and eosin.

For immunohistochemical (IHC) staining, sections from each mouse were reacted with anti-S. neurona serum prepared in a rabbit injected with culture-derived $S$. neurona merozoites as described (Dubey et al., 1999). The specificity of the $S$. neurona antiserum has been described (Dubey and Hamir, 2000). A Dako EnVision ${ }^{\mathbb{T I M}}$ peroxidase (Dako, Carpinteria, California) rabbit kit was used for staining, and the procedure recommended by the manufacturer was followed. Briefly, after deparaffinization, sections were treated with quenching solutions (3\% hydrogen peroxide in methanol), rinsed with water, digested in $0.4 \%$ pepsin, rinsed with BRIJ (Sigma, St. Louis, Missouri) detergent, rinsed in blocking solution $(0.5 \%$ casein $)$, treated with primary antibody (S. neurona serum diluted 1:5,000 with $1 \% \mathrm{BRIJ}$ ) at $37 \mathrm{C}$ for $30 \mathrm{~min}$ after rinsing treated with Dako EnVision kit-labeled polymer HRP solution, rinsed with buffer, treated with substrate 3-amino-9-ethylcarbazole, rinsed with buffer, counterstained with Mayer's hematoxylin, covered with Crystal Mount, air dried, mounted in Permount, and examined microscopically. Three experiments were performed.

The objective of experiment 1 was to study dose-related clinical sarcocystosis in KO mice fed $S$. neurona sporocysts of 2 isolates (SN28 OP, SN29-OP). Tenfold dilutions of sporocysts stored at $4 \mathrm{C}$ for 30 days were made in antibiotic saline, and aliquots $(0.5 \mathrm{ml})$ of $10^{-4}, 10^{-5}, 10^{-6}$, and $10^{-7}$ dilutions (estimated to contain $100,10,1$, or 0 organisms) were fed to $4 \mathrm{KO}$ mice (Table I). These dilutions were selected for bioassay because $\mathrm{KO}$ mice fed undiluted $\left(10^{\circ}\right)$ suspension of sporocysts became ill around 14 days after feeding sporocysts. Mice were observed for 56 days.
TABLE II. Infectivity of graded doses of Sarcocystis neurona merozoites of 2 isolates for gamma interferon knockout mice.

\begin{tabular}{|c|c|c|c|c|c|c|}
\hline \multirow[b]{2}{*}{ Dose* } & \multicolumn{3}{|c|}{ SN28-OP merozoites } & \multicolumn{3}{|c|}{ SN29-OP merozoites } \\
\hline & $\begin{array}{l}\text { Exam- } \\
\text { ined } \dagger\end{array}$ & $\mathrm{SAT}+$ & $\begin{array}{c}S . \\
\text { neurona }\end{array}$ & Examined & SAT & $\begin{array}{c}S . \\
\text { neurona }\end{array}$ \\
\hline \multirow[t]{4}{*}{$10^{6}$} & DK27 & ND & + & ND & ND & ND \\
\hline & DK27 & ND & + & ND & ND & ND \\
\hline & DK27 & ND & + & ND & ND & ND \\
\hline & DK27 & ND & + & ND & ND & ND \\
\hline \multirow[t]{4}{*}{$10^{5}$} & DK27 & ND & + & DK31 & ND & + \\
\hline & DK27 & ND & + & DK31 & ND & + \\
\hline & DK27 & ND & + & DK33 & ND & + \\
\hline & DK27 & ND & + & DK35 & ND & + \\
\hline \multirow[t]{4}{*}{$10^{4}$} & DK27 & ND & + & DK30 & ND & + \\
\hline & DK27 & ND & + & DK34 & ND & + \\
\hline & $\mathrm{DK} 27$ & ND & + & DK35 & ND & + \\
\hline & DK27 & ND & + & DK35 & ND & + \\
\hline \multirow[t]{4}{*}{$10^{3}$} & DK32 & ND & + & DK35 & ND & + \\
\hline & DK32 & ND & + & DK35 & ND & + \\
\hline & DK32 & ND & + & DK36 & ND & + \\
\hline & DK32 & $\mathrm{ND}$ & + & DK36 & ND & + \\
\hline \multirow[t]{4}{*}{$10^{2}$} & DK35 & $\geq 500$ & + & $\mathrm{K} 70$ & $<25$ & - \\
\hline & DK38 & ND & + & K70 & $<25$ & - \\
\hline & K67 & $<25$ & - & K70 & $<25$ & - \\
\hline & K67 & $<25$ & - & K70 & $<25$ & - \\
\hline \multirow[t]{4}{*}{10} & DK28 & ND & + & K70 & $<25$ & - \\
\hline & K67 & $<25$ & - & $\mathrm{K} 70$ & $<25$ & - \\
\hline & K67 & $<25$ & - & K70 & $<25$ & - \\
\hline & K67 & $<25$ & - & K70 & $<25$ & - \\
\hline \multirow[t]{4}{*}{1} & K53 & $<25$ & - & DK49 & $\geq 500$ & + \\
\hline & K67 & $<25$ & - & K54 & $<25$ & - \\
\hline & K67 & $<25$ & - & K70 & $<25$ & - \\
\hline & K67 & $<25$ & - & K70 & $<25$ & - \\
\hline
\end{tabular}

* Counted number of merozoites administered.

$\uparrow$ Clinical presentation and day postinoculation mouse was examined at necropsy. $\mathrm{K}$, killed; DK, killed when clinically ill.

\$ SAT, Sarcocystis neurona agglutination test. Values expressed as reciprocal titers.

$\S+, S$. neurona found in brain; - , S. neurona not found in brain.

The objective of experiment 2 was to compare the sensitivity of bioassay in cell culture versus $\mathrm{KO}$ mice to detect $S$. neurona in the inoculum. Schizonts and merozoites of $S$. neurona were grown in cell culture as described (Dubey et al., 1999). Free merozoites obtained from the tissue culture medium in flasks containing cultures of SN28-OP (passage 3, grown in M617 cells) and SN29-OP (passage 2, grown in equine kidney cells) were counted and diluted 10-fold in tissue culture medium until the last dilution contained 1 estimated merozoite (Table II). Aliquots $(0.5 \mathrm{ml})$ from the last 3 dilutions (estimated to have 100, 10 , and 1 merozoite) were inoculated onto 3 equine kidney cell culture flasks and injected s.c. into $\mathrm{KO}$ mice within $1 \mathrm{hr}$ of inoculation into cell cultures.

The objective of experiment 3 was to determine if sporocysts can be infective to $\mathrm{KO}$ mice by the s.c. route. For this, $2 \mathrm{KO}$ mice were inoculated s.c. with $\sim 10,000$ sporocysts of SN15-OP isolate, which had been stored for $10 \mathrm{mo}$ at $4 \mathrm{C}$.

All KO mice that developed neurologic signs had demonstrable $S$. neurona in their brains. Mice fed low numbers of sporocysts from isolates SN28-OP and SN29-OP became ill and were killed between 22 and 38 days after feeding sporocysts (DAFS) (Table I). The last dilution tested $\left(10^{-7}\right.$ dilution) was not infective to $\mathrm{KO}$ mice. The $10^{-6}$ and $10^{-5}$ dilutions of sporocysts were pathogenic to 10 of 16 mice and the $10^{-4}$ dilution was pathogenic to all 8 mice (Table I). Mice that survived 56 
DAFS had no SAT antibodies $(<1: 25)$ to $S$. neurona, and $S$. neurona parasites were not demonstrable in their tissues by immunohistochemistry. Sarcocystis neurona was found in the brains of 18 , lungs of 6 , eyes of 3 , hearts and stomachs of 2 , and tongue of 1 of the 18 of the KO mice with demonstrable $S$. neurona (Table I).

The dose-related response of $\mathrm{KO}$ mice injected with culture-derived merozoites is shown in Table II. All mice inoculated s.c. with 1,000 or more merozoites of both $S$. neurona isolates became ill between 3 and 4 wk postinoculation, and $S$. neurona was found in the brains of all infected mice. The infectivity of $\leq 100$ merozoites was erratic; only 3 of 24 mice injected with 1-100 merozoites of the SN28-OP and SN29$\mathrm{OP}$ isolates became infected. Antibodies to $S$. neurona were not found in sera of mice that survived for 67-72 days, and parasites were not demonstrable in their tissues.

The results of bioassay of merozoites in cell culture indicated that parasites injected into mice were viable. Of the 3 flasks inoculated with 100,10 , or 1 merozoite of the SN28-OP isolate, S. neurona was first seen in culture on the 27th day after inoculation with 100 and 10 merozoites. Organisms were not observed in the flask seeded with 1 merozoite. The cultures were discarded after 60 days of observation. Sarcocystis neurona organisms were seen in all 3 flasks 45 days after inoculation with 1, 10, or 100 merozoites of the SN29-OP isolate.

The reason for differences in infectivity of culture-derived merozoites for cell culture versus mice may be related to heterogeneous stages of the organism present in culture medium. Sarcocystis neurona undergoes asynchronous schizogony in cell culture, wherein a new population of schizonts may develop from merozoites without leaving the host cells (Lindsay et al., 1999). Merozoites of different ages are probably in the media and may differ in infectivity.

The $2 \mathrm{KO}$ mice inoculated s.c. with sporocysts developed clinical signs of infection, and $S$. neurona was found in their brains when killed 40 days after s.c. injection. Results indicate that $S$. neurona sporocysts can excyst when injected s.c. into KO mice. However, efficiency of the route (oral versus s.c.) of sporocysts to cause infection in $\mathrm{KO}$ mice needs to be compared.

\section{LITERATURE CITED}

Dubey, J. P. 2000. Prevalence of Sarcocystis species sporocysts in wild caught opossums (Didelphis virginiana). Journal of Parasitology 86: 705-710.

S. S. Black, L. G. Rickard, B. M. Rosenthal, D. S. Lindsay, S. K. Shen, O. C. H. Kwok, G. Hurst, and A. Rashmir-Raven. 2001. Prevalence of Sarcocystis neurona sporocysts in opossums (Didelphis virginiana) from rural Mississippi. Veterinary Parasitology, 95: 283-293.

, S. W. Davis, C. A. Speer, D. D. Bowman, A. DE Lahunta, D. E. Granstrom, M. J. Topper, A. N. Hamir, J. F. Cummings, AND M. M. SUTER. 1991. Sarcocystis neurona n. sp. (Protozoa: Apicom- plexa), the etiologic agent of equine protozoal myeloencephalitis. Journal of Parasitology 77: 212-218.

- AND A. N. HAMIR. 2000. Immunohistochemical confirmation of Sarcocystis neurona infections in raccoons, mink, cat, skunk and pony. Journal of Parasitology 86: 1150-1152.

- AND D. S. LINDSAY. 1998. Isolation in immunodeficient mice of Sarcocystis neurona from opossum (Didelphis virginiana) faeces, and its differentiation from Sarcocystis falcatula. International Journal for Parasitology 28: 1823-1828.

$\longrightarrow$, AND 1999. Sarcocystis speeri n. sp. (Protozoa: Sarcocystidae) from the opossum (Didelphis virginiana). Journal of Parasitology 85: 903-909.

- W. J. A. Saville, S. M. Reed, D. E. Granstrom, And C. A. SPEER. 2001. A review of Sarcocystis neurona and equine protozoal myeloencephatitis (EPM). Veterinary Parasitology, 95: 89-131.

, D. E. Mattson, C. A. Speer, R. J. Baker, D. M. Mulrooney, S. J. Tornquist, A. N. Hamir, And T. C. Gerros. 1999. Characterization of Sarcocystis neurona isolate (SN6) from a naturally infected horse from Oregon. Journal of Eukaryotic Microbiology 46: 500-506.

W. J. A. Saville, D. S. Lindsay, R. W. Stich, J. F. Stanek, C. A. Speer, B. M. Rosenthal, C. J. Nuoku, O. C. H. KwoK, S. K. Shen, AND S. M. ReED. 2000. Completion of the life cycle of Sarcocystis neurona. Journal of Parasitology 86: 1276-1280.

, C. A. Speer, And R. Fayer. 1989. Sarcocystosis of animals and man. CRC Press, Boca Raton, Florida, 215 p.

Fenger, C. K., D. E. Granstrom, A. A. Gajadhar, N. M. Williams, S. A. McCrillis, S. Stamper, J. L. Langemeier, and J. P. Dubey. 1997. Experimental induction of equine protozoal myeloencephalitis in horses using Sarcocystis sp. sporocysts from the opossum (Didelphis virginiana). Veterinary Parasitology 68: 199-213.

LindSAY, D. S., AND J. P. DuBEy. 2001. Direct agglutination test for the detection of antibodies to Sarcocystis neurona in experimentally infected animals. Veterinary Parasitology, 95: 179-186

- K. M. Horton, AND D. D. Bowman. 1999. Development of Sarcocystis falcatula in cell cultures demonstrates that it is different from Sarcocystis neurona. Parasitology 118: 227-233.

MacKay, R. J., S. W. Davis, AND J. P. Dubey. 1992. Equine protozoal myeloencephalitis. Compendium on Continuing Education for the Practicing Veterinarian 14: 1359-1367.

Marsh, A. E., B. C. Barr, J. Lakritz, R. Nordhausen, and P. A. CONRAD. 1997. Experimental infection of nude mice as a model for Sarcocystis neurona-associated encephalitis. Parasitology Research 83: 706-711.

Tanhauser, S. M., C. A. Yowell, T. J. Cutler, E. C. Greiner, R. J. MacKay, AND J. B. DAME. 1999. Multiple DNA markers differentiate Sarcocystis neurona and S. falcatula. Journal of Parasitology 85: 221-228. 